\title{
Policy networks in metropolitan regions: the case of the health system in Brazil
}

\section{| ${ }^{1}$ Juliana Pires de Arruda Leite, ${ }^{2}$ Ana Carolina Spatti, ${ }^{3}$ Matheus Leite de Campos I}

\begin{abstract}
Most policies, explicitly or implicitly, involve sharing responsibilities between different organizations, such as departments, government spheres, ministries, or private organizations. Thus, in recent decades, networks have become increasingly common in public policies. The Brazilian health system - given its size and geographic scope - is an example of complexity and sometimes fragmentation in policy implementation. In this context, the government adopts the concept of Healthcare Networks (RASs) in the operation of its health system. A characteristic that defines RASs is their regional character, since it is necessary to go beyond the municipal borders for the optimization of resources. This scenario of interregional relations becomes denser when the territory in question is configured in an urban superstructure, as is the case in metropolitan regions. Thus, this paper proposes the discussion of the case of Healthcare Networks in the Brazilian metropolitan regions and describes, in greater detail, the case of Campinas Metropolitan Region.
\end{abstract}

> Keywords: Healthcare Networks; health policy; Brazilian metropolitan regions.

\author{
${ }^{1}$ Universidade Estadual de \\ Campinas. Faculdade de Ciências \\ Aplicadas. Campinas-SP, Brasil \\ (juliana.leite@gmail.com, juliana. \\ leite@fca.unicamp.br). \\ ${ }^{2}$ Universidade Estadual de \\ Campinas. Faculdade de Ciências \\ Aplicadas. Campinas-SP, Brasil \\ (carolspatti@hotmail.com). \\ ${ }^{3}$ Universidade Estadual de \\ Campinas. Faculdade de \\ Ciências Aplicadas. Campinas- \\ SP, Brasil (matheusleite_98@ \\ hotmail.com).
}

Recebido em: 15/03/2016

Aprovado em: 08/09/2017 


\section{Introduction}

Health care systems are social responses deliberately organized to meet the demands and preferences of societies. In this sense, they must be linked to the health needs of these societies, which are expressed in unique demographic and epidemiological situations. There is, therefore, a close relationship between the evolution of the health conditions of a given population and the transition of health care systems.

For this reason, when an inconsistency between health conditions and the health care system occurs in any society, it highlights a crisis in the health care model. There is currently a global crisis in health systems, which reflects the mismatch between an epidemiological situation dominated by chronic conditions and a health care system aimed primarily at responding to acute conditions (MENDES, 2011).The World Health Organization (WHO) states that, historically, acute problems such as infectious diseases and traumas are the main concern of health care systems, and warns: "To cope with the rise of chronic conditions, it is imperative that health systems transpose this predominant model" (WHO, 2003, p. 46).

In this sense, new proposals to care for chronic conditions are gaining strength worldwide through a coordinated and continuous system. The notion of integrated health care is one of the pillars of Healthcare Networks $(\mathrm{HN})$, which are based on cooperation among managers, providers, and users. Contemporaneously, HN's took shape with integrated health systems deployed in the early 1990's in the United States. According to pioneering research in this country (SHORTELL et al., 1993), integrated systems for delivery of health services are characterized by: a focus on the health needs of the population; coordination and integration of care across a continuum; information systems that connect users, service providers and managers; information on costs, quality, and user satisfaction; use of financial incentives and organizational structures to align governance, managers, and health professionals in the pursuit of goals; and continuous improvement of the services provided.

Many countries have already had successful experiences in integrating their health systems by implementing Healthcare Networks. Brazil is advancing in this direction and in order to cope with most of the fragmentation difficulties, 
the Ministry of Health has sought to strengthen the design of networks in the operation of the National Health System (BRASIL, 2010).

One of the first steps towards the development of healthcare networks is the definition of a restricted population whose overall health will be under the network's care. The definition of this population involves a regionalization process, whereby "health regions" are defined. These health regions do not always coincide with the political and administrative boundaries, which raises the challenge of cooperative management in the network. Therefore an articulation of different bodies, agencies, and levels of government is necessary for the proper functioning of the network.

This scenario of inter-regional relations gains greater density when the territory is configured in an urban superstructure, as it is in the case of metropolitan regions. In these regions, the conurbation process dissolves the municipal administrative boundaries and requires cooperation between different cities in the search for economies of scale and scope in their health systems. In this sense, an analysis of the implementation of healthcare networks on a metropolitan scale is very fruitful.

Thus, this paper aims to discuss the cases of Healthcare Networks in Brazilian metropolitan regions, characterizing its implementation process as well as identifying management problems in various cases. One case is described in more details (Campinas Metropolitan Region). The study is based on data provided by agencies responsible for health management in the federal, state, and municipal levels, as well as primary data.

\section{The Brazilian Health System}

Until the 1930's, a national health system did not properly exist in Brazil. The effective state of health intervention began in this decade and consolidated its profile until the mid-1960's. The standard established in this period was a centralized federal government policy. Until the mid-1970's the system increased significantly, expanding service coverage to an increasing volume of users. However, this growth dictated the need to reform the system, which began to suffer from its own gigantic size. Thus, in the second half of the 1970's, pressures increased for reform based on the integration of the three levels of government (federal, state, and municipal) and decentralization. It is in this context that in 
1042 the 1980's, especially with the promulgation of the Federal Constitution (1988), the country began to form a new system of universal public health called the Unified Health System - UHS (DRAIBE; AURELIANO, 1989).

In 1993, the UHS Standard Operating Base marked the first steps of an administrative decentralization of the health system. This standard explicitly defined the municipality as the manager of health services and established the responsibilities and forms of funding. In addition, it established management arrangements between the three government levels (federal, state, and municipal) (BRASIL, 1993).

After the process of decentralization in the 1990's, regionalization has occupied a prominent role in the national health policy during the 2000's. In this context, agreements between the Ministry of Health and other levels of government to consider the welfare priorities of each state were signed, subdividing the system into regions and micro-regions of health (BRASIL, 2001).

The strategies toward comprehensive care went through the deployment and consolidation of a new model of primary care; the Family Health Program. This program is operated by multidisciplinary teams in primary healthcare units. Each team is responsible for monitoring a maximum of 4,000 inhabitants of a given area. The Family Health Program structured in local health systems has led to a major reorganization of the care model and produced positive results in major health indicators of the assisted populations (DAB, 2014).

The debate on the further integration of the health system acquired new emphasis from the publication of the document "Health Pact" (BRASIL, 2006), which emphasizes the importance of deepening the process of regionalization and organization of the system into an integrated manner. Advancing further in this direction in 2010, the Ministry of Health sought to strengthen the design of networks in the operation of the UHS, with the publication of one ordinance concerning the organization of the Healthcare Networks in it. The ordinance defined healthcare networks as "organizational arrangements of actions, and health services to be integrated by technical, logistical, and management support systems, seeking to ensure comprehensive care" (BRASIL, 2010, p. 4).

Since then, some implementation strategies have been established and are in progress for the construction of this new model of care in networks. Through 
technical and financial support, the Ministry of Health has prioritized and promoted the implementation of thematic networks, such as: "Stork Network" (Comprehensive care of pregnant, postpartum, and children up to 24 months), Emergency Care Network, Psychosocial Care Network (with priority for addressing alcoholism, crack addiction, and other drugs), Network of Care for Persons with Disabilities, Occupational Health Network, Elderly Health Network, among others (BRASIL, 2010).

Among the tools to manage these thematic networks, the most used in the Brazilian model is the creation of Lines of Care (LC), a form of joint resources and production practices among health care units in a given region for timely, responsive, and unique treatment of users by way of diagnosis and therapy. The goal is to coordinate care along the continuum and the connectivity of roles and tasks of different professionals and points of attention. The implementation of the LC occurs from the Primary Health Units, which have responsibility for care coordination and management of the network. Examples of lines of care implemented in the Brazilian system are: Arterial Hypertension Line Care, Diabetes Mellitus Line Care, Acute Myocardial Infarction Line Care, Stroke Line Care, Trauma Care Line, Breast Cancer Line Care and others (BRASIL, 2010).

\section{The metropolitan challenge}

In this section we intend to briefly characterize the Brazilian Metropolitan Regions (MRs) and contextualize them in the national health system. In addition, we seek to highlight some factors that make the integration of health services in these regions a complex challenge. Finally, we present the evidence found on the implementation of healthcare networks in some metropolitan regions.

The first metropolitan regions of Brazil were formally created between the 1960's and 1970's. Currently, there are 39 metropolises in Brazil, which are not only characterized by a concentration of most of the population and national wealth, but also by having significant pockets of poverty and social exclusion. The metropolitan municipalities differ substantially from each other as to the metropolization process, i.e., levels of population density and economic activities, which hinders the formulation of public policies for these regions. Table 1 characterizes the Brazilian metropolitan regions with respect to demographics. 
Table 1. Demographics of Brazilian metropolises, 2010

\begin{tabular}{|c|c|c|c|}
\hline Metropolitan Region & $\begin{array}{c}\text { Number of } \\
\text { municipalities }\end{array}$ & $\begin{array}{l}\text { Number of } \\
\text { inhabitants }\end{array}$ & $\begin{array}{c}\% \text { of the state } \\
\text { population }\end{array}$ \\
\hline São Paulo & 39 & 19683975 & $47,70 \%$ \\
\hline Rio de Janeiro & 19 & 11835708 & $74,02 \%$ \\
\hline Belo Horizonte & 48 & 5414701 & $27,63 \%$ \\
\hline Porto Alegre & 31 & 3958985 & $37,02 \%$ \\
\hline Brasília $^{2}$ & 22 & 3717728 & - \\
\hline Recife & 14 & 3690547 & $41,95 \%$ \\
\hline Fortaleza & 15 & 3615767 & $42,78 \%$ \\
\hline Salvador & 13 & 3573973 & $25,50 \%$ \\
\hline Curitiba & 26 & 3174201 & $30,39 \%$ \\
\hline Campinas & 19 & 2797137 & $6,78 \%$ \\
\hline Goiânia & 20 & 2173141 & $36,20 \%$ \\
\hline Manaus & 8 & 2106322 & $60,46 \%$ \\
\hline Belém & 6 & 2101883 & $27,73 \%$ \\
\hline Vitória & 7 & 1687704 & $48,01 \%$ \\
\hline Baixada Santista & 9 & 1664136 & $4,03 \%$ \\
\hline Natal & 10 & 1351004 & $42,64 \%$ \\
\hline São Luís & 5 & 1331181 & $20,25 \%$ \\
\hline João Pessoa & 13 & 1198576 & $31,82 \%$ \\
\hline Maceió & 11 & 1156364 & $37,06 \%$ \\
\hline Teresina & 14 & 1150959 & $36,91 \%$ \\
\hline NE Santa Catarina & 20 & 1094412 & $17,51 \%$ \\
\hline Florianópolis & 22 & 1012233 & $16,20 \%$ \\
\hline Aracaju & 4 & 835816 & $40,42 \%$ \\
\hline Cuiabá river & 4 & 833766 & $27,47 \%$ \\
\hline Londrina & 8 & 764348 & $7,32 \%$ \\
\hline Vale do Itajaí & 16 & 689731 & $11,04 \%$ \\
\hline
\end{tabular}




\begin{tabular}{|l|c|c|c|}
\hline Metropolitan Region & $\begin{array}{c}\text { Number of } \\
\text { municipalities }\end{array}$ & $\begin{array}{c}\text { Number of } \\
\text { inhabitants }\end{array}$ & $\begin{array}{c}\text { \% of the state } \\
\text { population }\end{array}$ \\
\hline Campina Grande & 23 & 687039 & $18,24 \%$ \\
\hline Petrolina/Juazeiro & 8 & 686410 & - \\
\hline Vale do Aço & 26 & 615297 & $3,14 \%$ \\
\hline Maringá & 13 & 612545 & $5,86 \%$ \\
\hline Agreste Alagoano & 20 & 601049 & $19,26 \%$ \\
\hline Cariri & 9 & 564478 & $6,68 \%$ \\
\hline Carbonífera & 25 & 550206 & $5,15 \%$ \\
\hline Foz do Itajaí & 9 & 532771 & $8,53 \%$ \\
\hline Macapá & 2 & 499466 & $74,60 \%$ \\
\hline Chapecó & 18 & 403494 & $6,46 \%$ \\
\hline Tubarão & 23 & 356721 & $5,71 \%$ \\
\hline Lages & 8 & 350532 & $5,61 \%$ \\
\hline Southwest Maranhão & 25 & 345873 & $5,26 \%$ \\
\hline
\end{tabular}

Source: The authors, based on IBGE, population census (2010).

The data show extensive heterogeneity with respect to the number of cities and population representativeness. The number of cities that make up the metropolitan regions (MRs) vary from two to 48. There are nine MRs which represent more than $40 \%$ of their state's population. There are also MRs composed of numerous small municipalities, which do not have a significant population. This can be explained by the fact that some states have more than one metropolitan area.

Regarding the health system in Brazil, the direct relationship of the Union with municipalities (a result of the decentralization process) imposed difficulties for the challenge of metropolitan health management. The gain of municipal autonomy contributed to generate an "institutional vacuum" in the metropolitan scale, to the extent that the metropolitan regions, although recognized by the Constitution, are not federal entities, i.e., autonomous units of government. This ambiguous legal situation emphasizes the difficulties in integrating the planning 
and implementation of health policy (among many other urban policies), and expresses a reality still quite permeated by conflicts and uncertainties about the compromising level of action (GARSON, 2007).

About the data on healthcare networks in metropolitan regions, evidence concerning the existence of HNs and Lines of Care in different metropolitan regions was obtained from several sources: state and municipal Departments of Health, scientific publications that report experiences, news reports and newsletters. As this is a recent process in consolidation in the country, for some MRs evidence of HN deployment was not found.

Evidence of HNs was found in 16 of 39 metropolitan regions. Due to the aforementioned recent ordinance of the Ministry of Health (2010), the experiences of $\mathrm{HN}$ are beginning to spread across the country. However, it is an ongoing process. Thus, the status progress analysis was made based on the following criteria:

- Status - incipient: Experiences reporting that teams of State Health Departments are discussing internally what $\mathrm{HN}$ are, performing educational processes to the central level for institutional support.

- Status - in consolidation: Experiences reporting development of the first steps in organizing $\mathrm{HN}$ : definition of health regions; mapping of resources and needs; approach with other actions; meeting of regional boards; defining flows.

- Status - consolidated: Experiences reporting results of networks in action through monitoring and evaluation indicators of $\mathrm{HN}$.

It is worth stating that this phenomenon takes place in $41 \%$ of the MRs. For all the records found in this study, nine (56\% of this subtotal) HN cases were classified as "incipient" and seven (44\%) as "in consolidation" process. No evidence cases already consolidated with published results were found. CONASS (2012) also found that in most states healthcare networks are in the early stages of their processes, which corroborates the evidence found for the metropolitan regions in this research. Table 2 presents data for the Healthcare Networks in metropolitan regions.

As a whole, the implementation experiences of 11 different thematic healthcare networks in metropolitan regions were registered. Undoubtedly the most developed thematic network so far is the "Stork Network" (SN - Comprehensive 
care for pregnant women, postpartum, and children), in 14 of the 16 regions. The second most important network deployment is the Emergency Care Network (in $9 \mathrm{MRs}$ ), followed by the Psychosocial Care Network (3 MRs), Elderly Health Network (3 MRs), Network of care for People with Disabilities (2 MRs), Occupational Health Network (2 MRs), Adolescent Health Network (2 MRs), Mental health Network (1 MR), and the Women Health Network (1 MR).

These results corroborate those found in CONASS (2012), which published the papers presented at the event "The State and Healthcare Networks: first show of experiences" This publication compiles the experiences of HNs in Brazil (not necessarily metropolitan regions). The results of this publication also show that the most developed network in the country is the "Stork Network," then the Emergency Care Network. 
1048

\begin{tabular}{|c|c|c|c|c|c|c|c|}
\hline 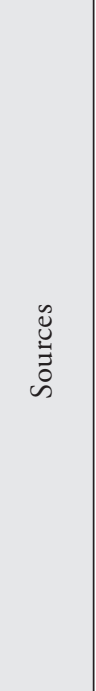 & 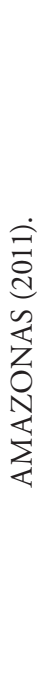 & 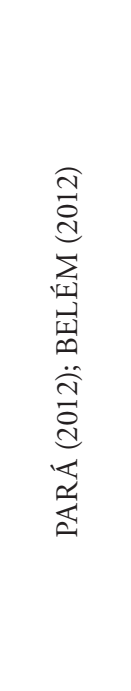 & 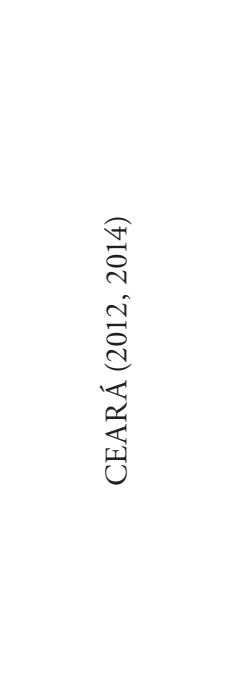 & 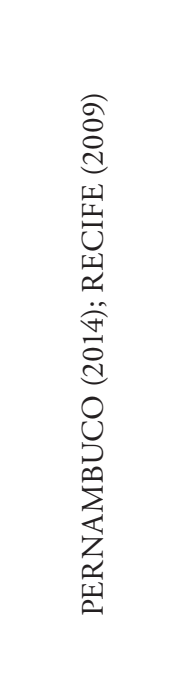 & 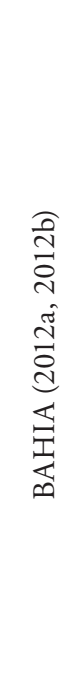 & 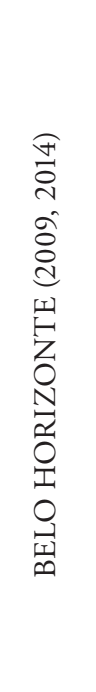 & 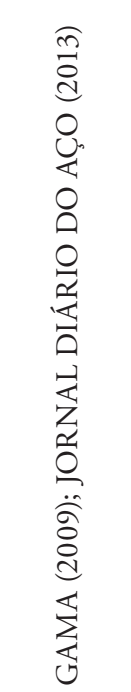 \\
\hline 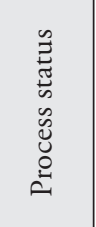 & 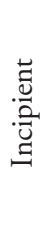 & 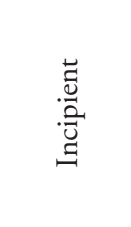 & 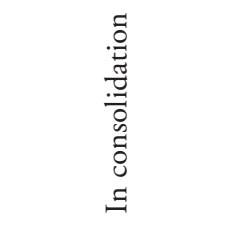 & 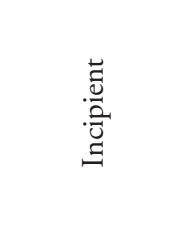 & 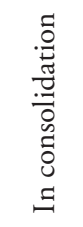 & 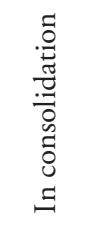 & 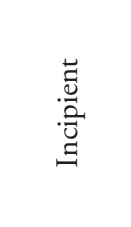 \\
\hline 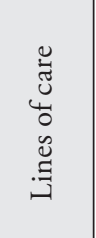 & 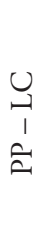 & 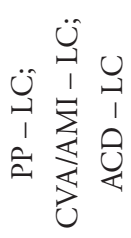 & 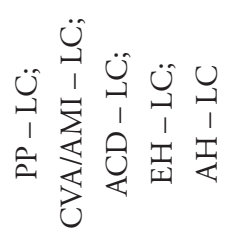 & 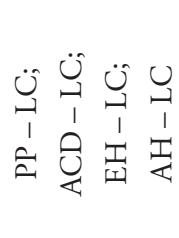 & 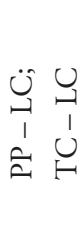 & 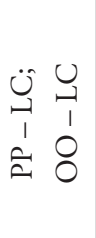 & 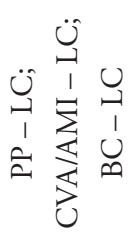 \\
\hline 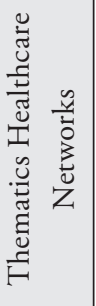 & Z & 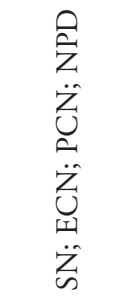 & 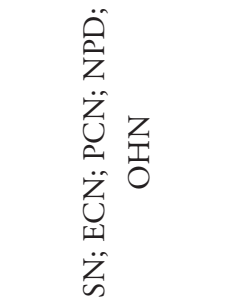 & 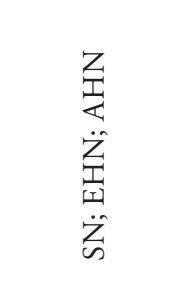 & $\begin{array}{l}z \\
\text { Zu } \\
\ddot{z} \\
\ddot{n}\end{array}$ & $\begin{array}{l}\text { Z } \\
\text { 至 } \\
\ddot{Z} \\
\text { 韭 } \\
\ddot{Z}\end{array}$ & 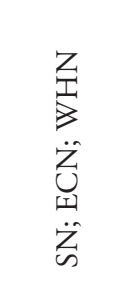 \\
\hline 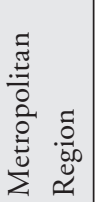 & $\begin{array}{l}\stackrel{0}{\tilde{J}} \\
\text { స్ } \\
\sum\end{array}$ & 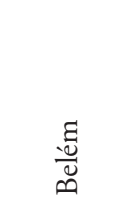 & 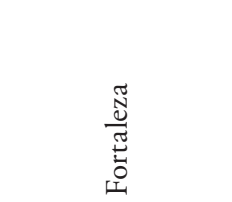 & 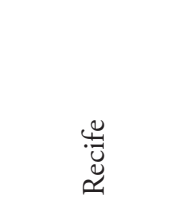 & $\frac{\overrightarrow{0}}{\frac{\tilde{D}}{\tilde{n}}}$ & 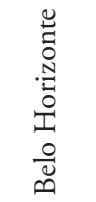 & \begin{tabular}{l}
8 \\
\multirow{4}{*}{} \\
0 \\
$\frac{0}{0}$ \\
$\frac{0}{j}$
\end{tabular} \\
\hline
\end{tabular}




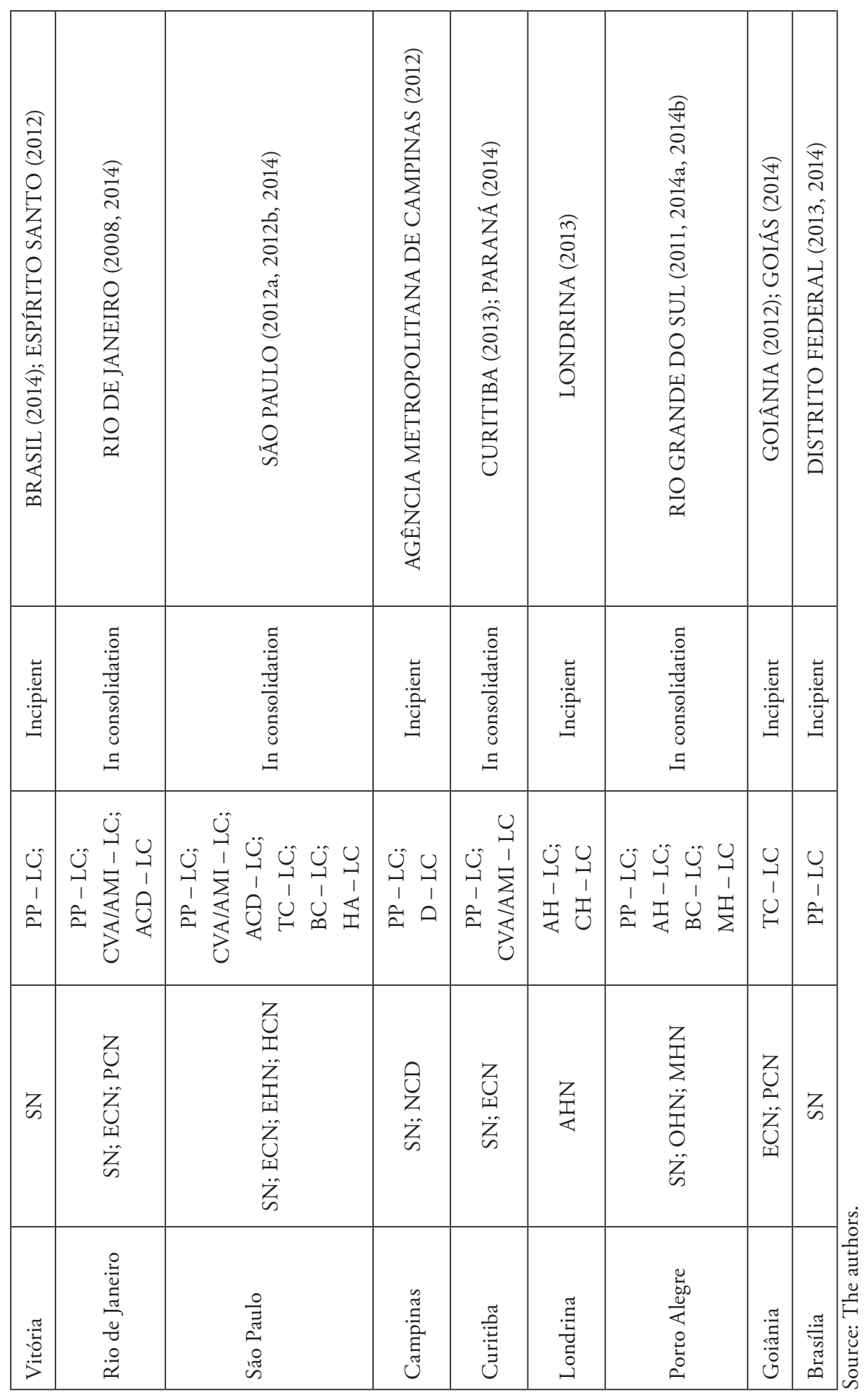




\section{SUBTITLES}

\section{Theme networks:}

SN - "Stork Network" (Comprehensive care to pregnant, postpartum and child)

ECN - Emergency Care Network

PCN - Psychosocial Care Network

NPD - Network of Care for Persons with Disabilities

OHN - Occupational Health Network

EHN - Elderly Health Network

AHN - Adolescent Health Network

HCN - Home Care Network

MHN -Mental health care Network

WHN - Women Health Network

NCD - Network of attention to chronic diseases

\section{Lines of Care:}

PP - LC: Pregnant and postpartum Line of Care

CVA/AMI - LC: Cerebrovascular accident (CVA) and Myocardial Infarction (AMI) Line of Care

ACD - LC: Coping with Alcohol, Crack and Other Drugs Line of Care

EH - LC: Elderly health Line of Care

AH - LC: Adolescent health Line of Care

$\mathrm{CH}$ - LC: Children health Line of Care

TC - LC: Traumatology and Cardiovascular Line of Care

$\mathrm{OO}$ - LC: Ophthalmology and otolaryngology Line of Care

BC - LC: Breast and Cervical Cancer Line of Care

HA - LC: Arterial Hypertension Line of Care

D - LC: Diabetes Line of Care

MH - LC: Mental Health Line of Care

\section{Campinas Metropolitan Region (CMR)}

In this section the case of one Metropolitan Region is presented in detail. Legally created in year 2000, Campinas Metropolitan Region (CMR) is a regional unit of the state of São Paulo composed of 19 municipalities (AGEMCAMP, 2014). Although its legal recognition formally occurred in 2000, the complexity of urban functions and the existing articulation among the different cities surrounding Campinas already made it act as a metropolitan region since the 
mid-1990s (LAVRAS, 2007). The CMR's territorial arrangement can be seen on

the following map (Figure 1):

Figure 1. Campinas Metropolitan Region (CMR)

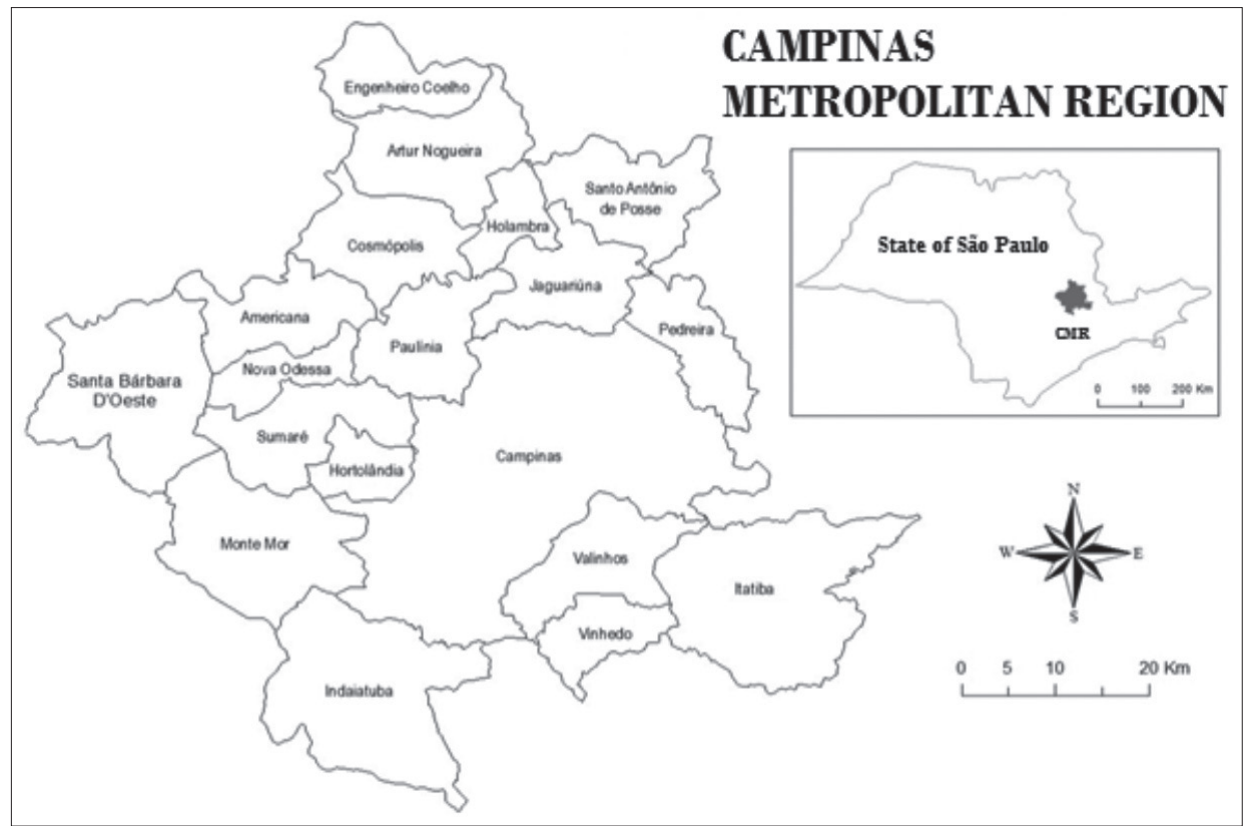

Source: Adapted from <www.mapasparacolorir.com.br>.

The regional unit has $3,645.16 \mathrm{~km}^{2}$ of territorial extension and 2,876,957 inhabitants, making it the second largest metropolitan region in the state of São Paulo, in terms of population (IBGE, 2012).

\section{The structuring process of Healthcare Networks in the CMR}

In order to structure the Healthcare Networks $(\mathrm{HcN})$ in the CMR, the development of a Metropolitan Health Plan (MHP) was needed. Such plan is based on the structuring of a metropolitan healthcare network as part of the Unified Health System's (UHS) qualifying process. So a partnership was established between the Center for Public Policy Studies (CPPS), from Campinas State University (UNICAMP), and the Campinas Metropolitan Agency (AGEMCAMP), with support from the Thematic Health Chamber (THC), a technical office conjoined with the CMR's Development Council (DC). 


\section{Participants involved}

The main contributors involved in the structuring process of the HcNs in the CMR were:

- Center for Public Policies Study - CPPS: considered a center of national reference in the field of public policies by the scientific community and both national and foreign promotion agencies of social diagnostics, governmental programs impact evaluation and health policies implementation. Its goals are the production, disclosure and application of knowledge in the interdisciplinary area of public policies. The Center is part of the State University of Campinas (UNICAMP).

- Campinas Metropolitan Agency - AGEMCAMP: autocracy of São Paulo’s State Government, established in 2003 to integrate the organization, planning and execution of common interest public functions in the CMR. Its attributions are to raise funds for investment in the metropolitan development and to establish plans, goals, programs and projects of common interest to the cities in the region. Other offices, such as the Regional Development Council and the Campinas Metropolitan Region's Development Fund (Fundocamp), are part of AGEMCAMP.

- Thematic Health Chamber - THC: technical office linked to CMR's Development Council (DC) and coordinated by a regional representative of the State of São Paulo Health Office. Its staff is composed of City Health Secretaries and technicians appointed by the latter.

- Regional Health Board VII - RHB VII: a sub-office of State of São Paulo Health Office, responsible for Campinas and its region.

\section{Formulation process}

The cooperation between the Center and the articulating party (AGEMCAMP) began in 2006. By then, and in order to subsidize the definition of the Metropolitan Health Plan (MHP), a document was created: "Diagnostics of the Health Sector in Campinas Metropolitan Region”. It included a profiling of the region's health situation, as well as an analysis of the health system's main weaknesses and strengths.

After the initial diagnostics, the process of formulating the MHP began in 2007, having as reference the following concept of "network", which was adopted by the CPPS/UNICAMP team: 
Organizational arrangements of functional units of health attention, diagnostic and therapeutic support, where procedures of different technological densities are developed and integrated by means of logistics, support and management systems, which aim at guaranteeing the integrality of care. (LAVRAS, 2011, p. 872).

The MHP formulation process was conducted by means of 20 workshops, mostly attended by health managers and technicians from the 19 cities of the CMR. The methodology applied for the Plan's development consisted of a strategic planning subsidized by the health diagnostic conducted earlier. The primary goal of the first meetings was to promote an alignment of the concepts which would guide the MHP evolution, such as: health system, service and attention networks, healthcare, lines of care and others.

Since technicians from the Municipal Health Offices and the São Paulo State Health Secretary both participated on the formulation stage, the interface between CPPS's consultancy and health managers was made possible.

As part of the strategic planning methodology, both an internal and external investigation was conducted in order to assess the UHS's main weaknesses and strengths in the region. Such analysis was important as it helped to uncover the environment in which the system has been developing itself, thus facilitating the formulation and definition of appropriate strategies regarding its consolidation, as well as contributing to the perceived potential of the $\mathrm{HcN}$ s in the CMR.

Furthermore on this same stage, and to facilitate the Metropolitan Plan's development and ensure the interface between the involved parties, a "socializing group" was formed. This group, which would be responsible for the implementation of the foreseen projects, had to actively participate on the process throughout its whole length, making sure to reinforce the continuity of discussions. Besides having the Municipal Health Secretaries and the Regional Health Department-VII director as its members, the group also included technicians from various fields. The result of this initial formulating stage was a technical document, which contained a preliminary proposal of the MHP, validated by AGEMCAMP and the THC.

After the preliminary document's approval, training was conducted with the socializing group. Besides that, short, mid and long term projects were defined. As a result, 47 detailed operational projects were drawn and divided by the HcN's components: Basic Care, Specialized/Urgent \& Emergent Care, Diagnostic and Therapeutic Support System (DTSS), Logistics System, Human Resources Management, Permanent Education and Healthcare and Management. 
Finally, the last stage of the MHP's formulation consisted of the unfolding of the operational plans into actions and activities, including budgeting, implementation schedule, expected results, institutional levels involved, execution stages, necessary resources and products. Table 3 describes and summarizes the activities performed during the formulation stage of the Metropolitan Health Plan:

Table 3. MHP's formulation stage

\begin{tabular}{|l|l|}
\hline & \multicolumn{1}{|c|}{ ACTIVITIES } \\
\hline - Definition of the THC/DC members who would take part on the Plan. \\
\hline - Structuring the socializing group. \\
\hline - Conceptual alignment and method presentation. \\
\hline - Workshops for the Plan's elaboration, including: definition of \\
priorities, indication of strategic goals, unfolding of strategies and \\
objectives to be reached.
\end{tabular}

Source: The authors. 


\section{Implementation process}

The MHP's formulation process was concluded in 2008. Later, the relationship between CPPS and AGEMCAMP was resumed and strengthened in 2009, this time having the common goal of implementing some of the Plan's operational projects.

Resources were accessed via the CMR's Development Fund (FUNDOCAMP) for the MHP's implementation process, which was also conducted by the socializing group, having full support from AGEMCAMP, the Regional Health Board (RHB) and the CPPS's team. Therefore, five projects were implemented:

1. Expansion of the Basic Health Units (BHU);

2. Computerization of the BHUs (implementation of the UHS card).

3. Structuring of Lines of Care and strengthening of Basic Healthcare through the implementation of the Pregnant and Puerperal Healthcare Line (PPHL)

4. Reference Model for Qualification of Regulatory Centrals.

5. Basic Healthcare's Permanent Education Plan formulation.

All projects are currently ongoing except for the second, which awaits availability of resources from the Health Ministry in order to start its implementation.

The first two projects demanded more resources and structural changes, which made its implementation to progress slowly. The last three projects, however, include advancements which are described next.

The implementation proposal of the PPHL on the UHS-SP (São Paulo) is an initiative that seeks to congregate efforts from every health professional involved in this process, particularly municipal and state managers, in order to guarantee accessibility and qualify the system's healthcare offered to pregnant and puerperal women. The structuring process of the PPHL was based on a methodology as shown on table 4 . 

(PPHL) in Campinas Metropolitan Region (CMR)

(1) Diagnostic analysis of the Pregnant and Puerperal Healthcare Line (PPHL) currently offered in Campinas Metropolitan Region (CMR), including focus point, support systems and management;

(2) Forming of a group called "Line Conductor Group" (CG), made of officially appointed professionals from the region's 19 municipalities and Campinas Region Health Department;

(3) Definition of guidelines, by the Thematic Health Chamber (THC), for elaborating the Line Structuring Plan designed by the CG;

(4) Training of the CG;

(5) Elaboration and proposal of a guide manual for process improvement of the Basic Healthcare Units. Is to be applied by the CG in selected Basic Units as to form a pilot in every municipality of the CMR;

(6) Formulation of a methodology expansion plan, which is to be applied on other Basic Units of the CMR;

(7) Follow-up and evaluation of this stage of line structuring. Source: The authors.

The Basic Healthcare Permanent Education Plan's formulating project aimed to subsidize and qualify the professionals and establish the necessary articulations to achieve permanent health education in the CMR. The more specific goal was to strengthen the role of Basic Healthcare, as coordinator of the Regional Healthcare Network and all healthcare regionally provided.

As for the Regulatory Centrals Qualification Reference Model, it focuses on Regulatory Standards, considering its relations to health planning, services contract making, control, evaluation, auditing and guarantee of access by users, both in municipal and regional levels. Regarding its context on the CMR, it was found that, in most region's municipalities, Regulation Centrals (RC) did not participate on the elaboration, monitoring and follow-up processes of contract making.

Figure 2, below, synthesizes the structuring process of the HcNs in the CMR. 


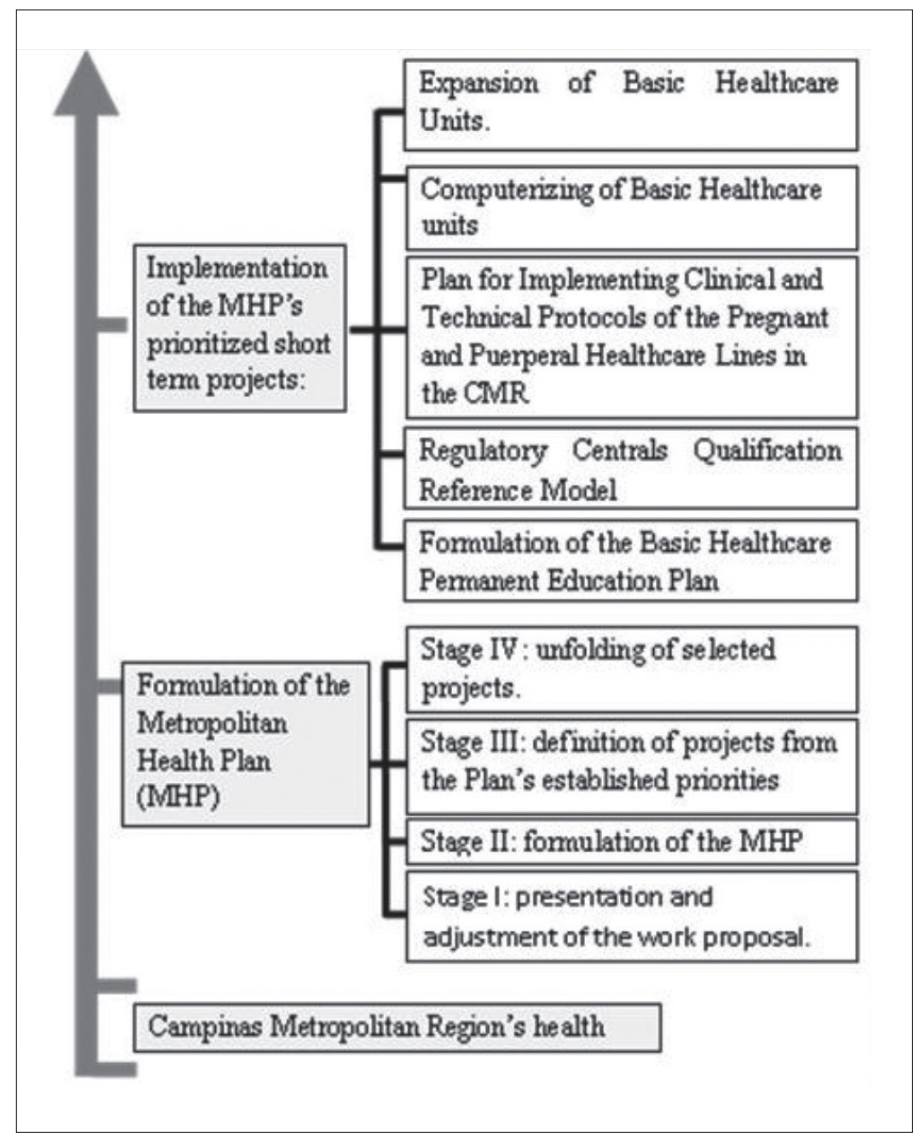

Source: The authors.

\section{Final remarks}

From the literature data and experiences studied, we could notice some points that represent advances in the consolidation of healthcare networks in Brazilian metropolitan region,s as well as points that express the difficulties and obstacles to be faced in this trajectory.

As advances we can cite the approach and integration movement between different areas of the state Health Departments in articulating shared planning and implementation of strategies and actions. In some cases this integration fostered the articulation of different projects and programs developed by optimizing the use of resources. Another positive point to be noted was the attempt to improve 
the dialogue among government levels (municipal, regional, state, and federal) for the convergence of projects and actions. Finally, the movement of dissemination and socialization of existing experiences in several institutions provides constant construction and consolidation dynamic for this new model of care.

On the other hand, some difficulties were quite clear, for example, the need to redefine the funding criteria that remain fragmented and dissociated from this new form of organization. In addition, several reports suggest that the integration of health professionals and information systems are the main challenges facing the consolidation of networks in the Brazilian health system. Other bottlenecks include the establishment of criteria to define the populations ascribed to health regions, the lack of commitment of some municipalities with planning activities, and the undeveloped culture of monitoring and evaluation of networks.

To these challenges is added the complex scenario of managing public policies on a metropolitan scale in which the geographical delimitation (metropolitan region) is not considered a federal entity, i.e., an autonomous government entity. This makes the process of formation of a unified and integrated health system complex. In this sense, the setting of a metropolitan system of health care becomes a huge challenge, since it presupposes the organization of a "regionally coordinated system", in a context where institutional mechanisms available to the regional level are more fragile and more dependent on the interests of actions. In this context the development of new forms of governance, tools, mechanisms, and institutional arrangements that favor the management of a regional healthcare network is imperative.

However, this scenario does not escape the expected. The Pan-American Health Organization (2010), analyzing $\mathrm{HcN}$ experiences across America, asserts that integration processes are difficult, complex, and long-term based. This is because the integration processes require larger systemic changes, not just isolated and targeted interventions. Considering this, one can say that Brazil is taking key steps toward this structural and systemic change in their health system.

The CMR's case confirms the challenge of integrating the Brazilian Unified Health System in order to face the rapid growth of chronic conditions. In this sense, the CMR's case manifests the need for restructuring the health care system from the $\mathrm{HcN}$ perspective. Moreover, despite the existence of intramunicipal specificities and of a set of challenges to be overcome in the region, the CMR 
behaves like a regional unit of greater autonomy in relation to the provision of healthcare within the UHS, with actual conditions to contribute to the coping of the system integration challenge.

The expected result of the CMR's Metropolitan Health Plan is that it becomes a management tool for structuring Networks for Health Care in other metropolitan areas.

\section{References}

AGÊNCIA METROPOLITANA DE CAMPINAS (AGEMCAMP). 2014. Disponível em: $<$ http://www.sdmetropolitano.sp.gov.br/portalsdm/agemcamp.jsp>. Acesso em: 9 out. 2014. . 2012. Disponível em: http://www.agemcamp.sp.gov.br/ Acesso em: 30 abr. 2014. AMAZONAS. Secretaria de Estado de Saúde. Plano Estadual de Saúde (2012 - 2015). 2011. Disponível em: https://www2.mp.pa.gov.br/sistemas/gcsubsites/upload/37/PES-20122015.pdf. Acesso em: 27 abr. 2014.

AURELIANO, L. M.; DRAIBE, S. M. A especificidade do welfare state brasileiro. Reflexóes sobre a natureza do bem-estar. LC/BRS/L. Brasília, v. 3, p.86-178, 1989.

BAHIA. Secretaria de Saúde. Plano de Ação da Rede de Atenção às Urgências - Regiáo Metropolitana de Salvador Ampliada. 2012b. Disponível em: http://www.saude.ba.gov.br/ index.php?option=com_content=101. Acesso em: 28 abr. 2014.

BELÉM. Limites territoriais do Município de Belém e Região Metropolitana. 2012. Disponível em: http://www.belem.pa.gov.br/ppa/projeto/5.\%20ANEXO\%20I\%20-\%20PPA\%2020142017.pdf. Acesso em: 27 abr. 2014.

BELO HORIZONTE. Secretaria Municipal De Saúde. SUS-BH: Cidade saudável. Plano macroestratégico (2009-2012). 2009. Disponível em: <portalpbh.pbh.gov.br/pbh/ecp/files. do?evento=download...pms...> Acesso em: 28 abr. 2014.

BELO HORIZONTE. Subsecretaria De Participação Popular. 2014. Disponível em: http:// gestaocompartilhada.pbh.gov.br/estrutura-territorial/areas-de-abrangencia-dos-centros-desaude. Acesso em: 28 abr. 2014.

BRASIL. Ministério da Saúde. Portaria no 545, de 20 de maio de 1993. Disponível em: $<$ http://bvsms.saude.gov.br/bvs/saudelegis/gm/1993/prt0545_20_05_1993.html>. Acesso em: 19 set. 2013.

. Ministério da Saúde. Portaria no 95, de 26 de janeiro de 2001. Disponível em: $<$ http://bvsms.saude.gov.br/bvs/saudelegis/gm/2001/prt0095_26_01_2001.html>. Acesso em: 19 set. 2013.

. Ministério da Saúde. Portaria no 399/GM. 2006. Disponível em: <http://dtr2001. saude.gov.br/sas/PORTARIAS/Port2006/GM/GM-399.htm>. Acesso em: 14 abr. 2014. 
Ministério da Saúde. Portaria no 4.279, de 30 de dezembro de 2010. Disponível em: <conselho.saude.gov.br/ultimas.../img/07_jan_portaria4279_301210.pdf>. Acesso em: 9 mar. 2013.

- Ministério Da Saúde. DAB: Departamento De Atenção Básica. 2014. Brasília. Disponível em: http://dab.saude.gov.br/atencaobasica.php. Acesso em: 3 dez. 2013.

. Ministério da Saúde. Saúde implanta S.O.S Emergências no Espírito Santo. 2014. Disponível em: http://www.brasil.gov.br/saude/2014/02/saude-implanta-s-o-s-emergenciasno-espirito-santo. Acesso em: 23 abr. 2014.

. Ministério da Saúde. Datasus - Sistema de Informaçôes Ambulatoriais do SUS (SUS SIA / SUS). 2012. Disponível em: http://tabnet.datasus.gov.br/cgi/idb2012/matriz. htm\#demog. Acesso em: 22 mar. 2014.

Ministério da Saúde. Cadastro Nacional de Estabelecimentos de Saúde (CNES). 2012. Disponível em: <http://tabnet.datasus.gov.br/cgi/idb2012/matriz.htm\#demog>. Acesso em: 22 mar. 2014.

CEARÁ. Secretaria Estadual de Saúde. 2014. Disponível em: < http://www.saude.ce.gov.br/ index.php/noticias/46282-curso-vai-melhorara-atencao-a-urgencias-em-hospitaisAccessed on 04/27/2013>. Acesso em: 27 abr. 2014.

. Plano Estadual de Saúde (2012 - 2015). 2012. Disponível em: www.saude.ce.gov. br/index.php/...de.../plano-estadual-da-saude. Acesso em: 27 abr. 2014.

CURITIBA. Secretaria Municipal de Saúde. 2013. Programa Mãe Curitibana. Disponível em: http://www.maecuritibana.com.br/. Acesso em: 30 abr. 2014.

DAWSON, B. Informe Dawson sobre el futuro de los servicios médicos y afines. Washington, DC: Pan American Health Organization, 1964.

DIÁRIO DO AÇO JOURNAL. 2013. Disponível em: http://www.diariodoaco.com.br/ noticias.aspx?cd=70637. Acesso em: 23 abr. 2014.

DISTRITO FEDERAL. Departamento de Saúde. 2014. Disponível em: http://www.saude. df.gov.br/. Acesso em: 30 abr. 2014.

DISTRITO FEDERAL. Secretaria de Desenvolvimento da Regiāo Metropolitana. 2013. [Online] Disponível em: http://www.entorno.df.gov.br/. Acesso em: 30 abr. 2014.

. Rede de atenção à urgência. 2012a. Disponível em: http://www.saude.ba.gov. br/images/arquivos/Saude_Toda_Hora/Plano_RMSA__REVISADO_MAIO_2012.pdf. Acesso em: 28 abr. 2014.

ESPÍRITO SANTO. Secretaria Estadual de Saúde. Plano Estadual de Saúde (2012 2015). 2012. Disponível em: http://www.saude.es.gov.br/Download/Plano_Estadual_de_ Saude_2012_2015.pdf Acesso em: 23 abr. 2014. 
GAMA, F. N. A saúde da mulher trabalhadora no sistema público de saúde: um estudo de caso. 2009. Disponível em: <http://www.livrosgratis.com.br/arquivos_livros/cp120097. pdf>Acesso em: 23 abr. 2014.

GARSON, S. Regiôes Metropolitanas: obstáculos institucionais à cooperação em políticas urbanas. Rio de Janeiro: IPPUR/UFRJ, 2007. Disponível em: <http://teses.ufrj.br/ IPPUR_D/SolGarsonBraulePinto.pdf>. Acesso em: 22 mar. 2014.

GOIÂNIA. Secretaria Municipal de Saúde. 2012. Disponível em: http://www.saude. goiania.go.gov.br/html/secretaria/sus/Cais-Ciams-Centros.shtml. Acesso em: 30 abr. 2014.

GOIÁS. Secretaria de Saúde. 2014. Disponível em: http://www.saude.go.gov.br/index. php?idMateria=161090. Acesso em: 30 abr. 2014.

INSTITUTO BRASILEIRO DE GEOGRAFIA E ESTATÍSTICA. Censo populacional. 2010a. Brasilia. Disponível em: http://censo2010.ibge.gov.br/ Acesso em: 22 mar. 2014.

LAVRAS, C. Atenção primária à saúde e a organização de redes regionais de atenção à saúde no Brasil. Saúde soc. São Paulo, v. 20, n. 4, p. 867-874, dez 2011. Disponível em: <http:// www.scielo.br/scielo.php?script=sci_arttext\&pid=S0104-12902011000400005\&lng=en\&n rm=iso >. Acesso em: 9 nov. 2017.

. (Coord). Diagnóstico do setor da saúde da RMC. Campinas: NEPP-Núcleo de Estudos de Políticas Públicas/PESS - Programa de Estudos em Sistemas de Saúde/UNICAMP, 2007. Disponível em: http://www.agemcamp.sp.gov.br. Acesso em: 9 out. 2014.

LONDRINA. Secretaria Municipal de Saúde. Relatório anual de Gestão da Saúde. 2013.

Disponível em: http://www.londrina.pr.gov.br/dados/images/stories/Storage/sec_saude/ relatorios_gestao/relatorio_gestao_2013.pdf. Acesso em: 30 abr. 2014.

MENDES, E. V. As Redes de Atenção à Saúde. Pan American Health Organization. 2a ed. Brasília. 2011. Disponível em: www.paho.org/bra/index.php?option=com_docman\&task. Acesso em: 19 dez. 2014.

NÚCLEO DE ESTUDOS DE POLÍTICAS PÚBLICAS. 2014. [Online] Disponível em: http://www.nepp.unicamp.br/index.php/sobre-nepp/sobre Acesso em: 9 out. 2014.

PAN-AMERICAN HEALTH ORGANIZATION. Redes integradas de servicios de salud: conceptos, opciones de politica y hoja de ruta para su implementacion em las Americas. Washington, DC: PAHO, 2010.

PARÁ. Secretaria de Saúde. Plano Estadual de Saúde (2012-2015). 2012. Disponível em: https://www2.mp.pa.gov.br/sistemas/gcsubsites/upload/37/PES-2012-2015.pdf Acesso em: 27 abr. 2014.

PARANÁ. Coordenação da Região Metropolitana De Curitiba. 2014. Disponível em: http://www.comec.pr.gov.br/ Acesso em: 30 abr. 2014. 
PERNAMBUCO. Secretaria de Saúde. 2014. [Online] Disponível em: http://portal.saude. pe.gov.br/secretaria-executiva-de-coordenacao-geral/gerencias-regionais-de-saude. Acesso em: 29 abr. 2014.

RECIFE. Secretaria Municipal de Saúde. Plano Municipal de Saúde (2010/2013). 2009. [Online] Disponível em: http://www.recife.pe.gov.br/noticias/arquivos/5916.pdf . Acesso em: 28 abr. 2014.

RIO DE JANEIRO. Database. Disponível em: <http://portalgeo.rio.rj.gov.br/indice/ flanali.asp?codpal=1187>. Acesso em: 30 abr. 2014.

RIO DE JANEIRO. Secretaria se Saúde. Redes de Atenção à Saúde. 2014. Disponível em: http:// www.saude.rj.gov.br/atencao-a-saude-1/946-redes-tematicas.html. Acesso em: 30 abr. 2014.

RIO GRANDE DO SUL. Secretaria de Saúde. 2011. Disponível em: http://www1.saude. rs.gov.br/dados/1334679241358plano\%20de\%20acao\%20regional\%20inicial_RS.pdf. Acesso em: 30 abr. 2014.

. 2014a. Disponível em: http://www.saude.rs.gov.br/conteudo/462/?Pol\%C3\%ADticas

de_Sa\%C3\%BAde_do_Rio_Grande_do_Sul Acesso em: 30 abr. 2014.

.2014b. Disponível em: http://www.saude.rs.gov.br/conteudo/515/?Linhas_de_Cuidado. Acesso em: 30 abr. 2014.

SÃO PAULO. Conselho De Secretários Municipais De Saúde. 2012. Disponível em: http:// www.cosemssp.org.br/downloads/Cursos/Urgencia-Emergencia-Jose-06-03.pdf. Acesso em: 30 abr. 2014.

SÃO PAULO. Secretaria de Saúde. 2012. Disponível em: <http://www.saude.sp.gov.br/ resources/ces/homepage/rras/fatima_-_apresentacaoredesatualizado_junho_12.pdf>. Acesso em: 2 maio 2014.>

SÃO PAULO. Subsecretaria de Assuntos Metropolitanos. 2014. Disponível em: <http:// www.sdmetropolitano.sp.gov.br/portalsdm/sao-paulo.jsp>. Acesso em: 30 abr. 2014.

SHORTELL, S. M. et al. Creating organized delivery systems: the barriers and the facilitators. Journal of Healthcare Management, v. 38, n. 4, p. 447-466, 1993.

WORLD HEALTH ORGANIZATION. Diet, nutrition and the prevention of chronic diseases. Geneva: WHO, 2003. Disponível em: <http://cdrwww.who.int/nutrition/ publications/public_health_nut9.pdf>. Acesso em: 2 jul. 2014.

\section{Notes}

${ }^{1}$ Redes de Atenção à Saúde (RASs), in Portuguese.

${ }^{2}$ The original concept of structuring Healthcare Networks dates back to the Dawson Report, published in 1920 in England (DAWSON, 1964). This report highlighted some key points such as the integration of preventive and curative medicine, the central role of the general practitioner, and the entrance through Primary Health Care. 
${ }^{3}$ Sistema Único de Saúde (SUS), in Portuguese.

${ }^{4}$ Arranjos organizativos de ações e serviços de saúde, de diferentes densidades tecnológicas, que integradas por meio de sistemas de apoio técnico, logístico e de gestão, buscam garantir a integralidade do cuidado.

${ }^{5}$ Due to the aforementioned difficulty of institutional consolidation of the metropolitan regions as healthcare management units, the search for evidences regarding Healthcare Networks in Brazilian metropolitan regions was conducted by a diversity of procedures as follows:

1. Metropolitan region's website search (healthcare activities);

2. Main metropolitan cities' website search (reports of inter-cities healthcare activities);

3. State Health Office's website search (health consortium's reports);

4. Phone calls to healthcare departments of main metropolitan cities (reports of ongoing healthcare projects on the metropolitan context);

5. Bibliographical research of scientific articles on the subject - only CONASS (2012) was found.

The experiences collected by these five research procedures were divided into three categories, according to their development level. Most experiences reported educational processes of network model formation and diffusion. Only a few reported ongoing organizational processes and none provided a fully functional network example.

${ }^{6}$ Arranjos organizativos de unidades funcionais de saúde, pontos de atenção e apoio diagnóstico e terapêutico, onde são desenvolvidos procedimentos de diferentes densidades tecnológicas que, integrados através de sistemas de apoio e de gestão, buscam garantir a integralidade do cuidado.

${ }^{7}$ J. P. A. Leite participou da caracterização e contextualização das regiôes metropolitanas brasileiras. A. C. Spatti participou do detalhamento do processo de formação das redes na Regiấo Metropolitana de Campinas. M.L. de Campos participou da elaboração do resumo, da introduçáo das consideraçôes finais e descrição do sistema de saúde brasileiro. 
Redes de politicas nas regióes metropolitanas: $o$ caso do sistema de saúde brasileiro

A maior parte das políticas, explícita ou implicitamente, envolve o compartilhamento de responsabilidades entre diferentes organizaçóes, tais como departamentos, esferas governamentais, ministérios ou organizaçôes privadas. Dessa forma, em décadas recentes, as redes têm se tornado cada vez mais comuns nas políticas públicas. $\mathrm{O}$ sistema de saúde brasileiro - dado seu tamanho e escopo geográfico - é um exemplo de complexidade e, por vezes, de fragmentação na implementação de políticas. Nesse contexto, o governo adota o conceito de Redes de Atenção à Saúde (RASs) na operação de seu sistema de saúde. Uma característica que define as RASs é seu caráter regional, já que se faz necessário ir além das fronteiras municipais para a otimização de recursos. Esse cenário de relaçóes inter-regionais ganha maior densidade quando o território em questão se encontra configurado numa superestrutura urbana, como é o caso das regióes metropolitanas. Assim, este artigo propóe a discussão do caso das Redes de Atenção à Saúde nas regiôes metropolitanas brasileiras e descreve, em maiores detalhes, o caso da Região Metropolitana de Campinas.

> Palavras-chave: Redes de Atenção à Saúde; política de saúde; regiões metropolitanas brasileiras. 